\title{
Prophylactic circumferential cryopexy: a retrospective study of 106 eyes
}

\author{
J. A. A. GOVAN \\ From the Retina Unit, Moorfields Eye Hospital, High Holborn, London WCIV $7 A N$
}

SUMMARY A retrospective study of 106 eyes which have undergone prophylactic circumferential cryopexy is presented. The complications involving the anterior segment were iritis, transient cycloplegia, a fixed dilated pupil, and cataract formation. Those involving the posterior segment were vitreous, subchoroidal and retinal haemorrhage, and preretinal fibrosis. The incidence of retinal detachment was $7.5 \%(8 / 106)$ after an average follow-up of 33 months. The importance of a confluent cryopexy choroidoretinal reaction is demonstrated. The indications are reviewed and a rationale for the technique of application is proposed.

In 1972 Campbell and Rittler ${ }^{1}$ suggested the use of prophylactic circumferential cryopexy (PCC) prior to cataract extraction in patients prone to retinal detachment. They and others ${ }^{2} 3$ reported that, despite meticulous preoperative assessment, with treatment of predisposing retinal degeneration, retinal detachment still occurred with a relatively high frequency $(25-43 \%)$ after cataract extraction in fellow eyes of aphakic retinal detachments (ARD), and that the retinal breaks occurred in areas of retina that were ophthalmoscopically normal. Hudson and Kanski ${ }^{3}$ reported the use of PCC in 18 fellow eyes of ARDs with no complications. Robertson and Prilack ${ }^{4}$ reported 2 cases of early retinal detachment and 1 case of preretinal membrane formation following PCC.

At some retinal units PCC is an accepted prophylactic treatment of selected second eyes which have a high risk of retinal detachment. This paper is a retrospective study of 106 eyes which have undergone PCC to ascertain the efficacy and morbidity and thus to attempt to clarify the indications.

\section{Patients and methods}

The records of all patients who had undergone PCC at this hospital during the past 9 years were reviewed. Those cases with inadequate documentation, or with a follow-up period of less than 6 months, or who had retinal detachment surgery within the previous 10 years were excluded ( 12 cases). Cases were classified according to the pathology in

Correspondence to Mr J. A. A. Govan. the fellow eye (FE) or treatment eye (TE) such that comparisons could be made with statistics in the literature.

Group I consisted of 28 eyes with fellow eyes with previous phakic retinal detachments which were subgrouped into: (a) giant tear FE (18 eyes); $(b)$ high myopia both eyes ( 7 eyes); (c) extensive peripheral retinal degeneration TE ( 3 eyes).

Group II consisted of 60 eyes with fellow eyes with previous ARDs which were subgrouped into: (a) treated congenital cataracts both eyes (5 eyes); (b) senile cataracts both eyes; PCC prior to lens extraction (32 eyes); (c) senile caratacts both eyes; PCC after lens extraction (23 eyes).

Group III consisted of 17 eyes with high myopia with no retinal detachment history and were subgrouped into: (a) senile cataracts both eyes; PCC prior to lens extraction (8 patients, 11 eyes); (b) extensive peripheral retinal degeneration TE (4 patients, 6 eyes). In addition there was 1 case ( 1 eye) with a very strong family history of retinal detachments.

\section{PATHOLOGY IN TREATMENT EYE}

The nine eyes with extensive peripheral retinal degeneration all had extensive lattice degeneration with small round holes, and one of these had a small peripheral localised retinal detachment. Of the remaining 97 eyes there were 2 small localised retinal detachments, 1 round hole, 1 dialysis, 1 case of a snail track degeneration, and 12 eyes with lattice degeneration of which 4 had multiple small round holes within the lattice. Three patients had previous retinal detachment surgery at least 20 years prior to 
PCC. In addition there were 2 cases of Marfan's syndrome with subluxated lenses and one of Marchesani's syndrome with congenital cataracts aspirated in childhood.

Results

The age distribution, refraction, and follow-up periods after cryopexy are categorised in Table 1, 2 , and 3 respectively. All refractions are spherical equivalents and aphakic refractions have been converted to phakic refractions according to the formula phakic refraction $=($ aphakic refraction -8$)$ $\times 2.5$

PCC was administered in one $360^{\circ}$ stage in 25 eyes, in two $180^{\circ}$ stages in 78 eyes, and in one

Table 1 Age distribution

\begin{tabular}{|c|c|c|c|c|c|c|c|c|c|c|}
\hline \multirow{3}{*}{$\begin{array}{l}\text { Age } \\
\text { distribution } \\
\text { (years) }\end{array}$} & \multicolumn{3}{|c|}{$\begin{array}{l}\text { I. Phakic detachment } \\
\text { fellow eye }\end{array}$} & \multicolumn{3}{|c|}{$\begin{array}{l}\text { II. Aphakic detachment } \\
\text { fellow eye }\end{array}$} & \multicolumn{2}{|c|}{ III. High myopia } & \multirow{3}{*}{$\begin{array}{l}\text { Strong } \\
\text { family } \\
\text { history of } \\
\text { retinal } \\
\text { detachment }\end{array}$} & \multirow{3}{*}{$\begin{array}{l}\text { Total } \\
t\end{array}$} \\
\hline & \multirow{2}{*}{$\begin{array}{l}\text { (a) Giant } \\
\text { tear (FE) }\end{array}$} & \multirow{2}{*}{$\begin{array}{l}\text { (b) High } \\
\text { myopia }\end{array}$} & \multirow{2}{*}{$\begin{array}{l}\text { (c) Extensive } \\
\text { peripheral } \\
\text { retinal } \\
\text { degeneration } \\
(T E)\end{array}$} & \multirow{2}{*}{$\begin{array}{l}\text { (a) Treated } \\
\text { congenital } \\
\text { cataracts }\end{array}$} & \multicolumn{2}{|c|}{ Senile cataracts } & \multirow{2}{*}{$\begin{array}{l}\text { (a) PCC } \\
\text { prior to } \\
\text { lens ex- } \\
\text { traction }\end{array}$} & \multirow{2}{*}{$\begin{array}{l}\text { (b) Extensive } \\
\text { peripheral } \\
\text { retinal } \\
\text { degeneration }\end{array}$} & & \\
\hline & & & & & $\begin{array}{l}\text { (b) PCC } \\
\text { prior } \\
\text { to lens } \\
\text { extraction }\end{array}$ & $\begin{array}{l}\text { (c) PCC } \\
\text { after lens } \\
\text { extraction }\end{array}$ & & & & \\
\hline $10-20$ & 4 & 2 & 1 & & & & & & 1 & 8 \\
\hline $21-40$ & 8 & & 2 & 2 & & 1 & & 3 & & 16 \\
\hline $41-60$ & 6 & 2 & & 3 & 11 & 8 & 5 & 3 & & 38 \\
\hline $61+$ & & 3 & & & 21 & 14 & 6 & & & 44 \\
\hline Total & 18 & 7 & 3 & 5 & 32 & 23 & 11 & 6 & 1 & 106 \\
\hline
\end{tabular}

Table 2 Refraction

\begin{tabular}{|c|c|c|c|c|c|c|c|c|c|c|}
\hline \multirow[t]{3}{*}{ Myopia } & \multicolumn{3}{|c|}{$\begin{array}{l}\text { I. Phakic detachment } \\
\text { fellow eye }\end{array}$} & \multicolumn{3}{|c|}{$\begin{array}{l}\text { II. Aphakic detachment } \\
\text { fellow eye }\end{array}$} & \multicolumn{2}{|c|}{ III. High myopia } & \multirow{3}{*}{$\begin{array}{l}\text { Strong } \\
\text { family } \\
\text { history of } \\
\text { retinal } \\
\text { detachment }\end{array}$} & \multirow{3}{*}{ Total } \\
\hline & \multirow{2}{*}{$\begin{array}{l}\text { (a) Giant } \\
\text { tear (FE) }\end{array}$} & \multirow{2}{*}{$\begin{array}{l}\text { (b) High } \\
\text { myopia }\end{array}$} & \multirow{2}{*}{$\begin{array}{l}\text { (c) Extensive } \\
\text { peripheral } \\
\text { retinal } \\
\text { degeneration } \\
(T E)\end{array}$} & \multirow{2}{*}{$\begin{array}{l}\text { (a) Treated } \\
\text { congenital } \\
\text { cataracts }\end{array}$} & \multicolumn{2}{|c|}{ Senile cataracts } & \multirow{2}{*}{$\begin{array}{l}\text { (a) PCC } \\
\text { prior to } \\
\text { lens ex- } \\
\text { traction }\end{array}$} & \multirow{2}{*}{$\begin{array}{l}\text { (b) Extensive } \\
\text { peripheral } \\
\text { retinal } \\
\text { degeneration }\end{array}$} & & \\
\hline & & & & & $\begin{array}{l}\text { (b) PCC } \\
\text { prior to } \\
\text { lens } \\
\text { extraction }\end{array}$ & $\begin{array}{l}\text { (c) PCC } \\
\text { after lens } \\
\text { extraction }\end{array}$ & & & & \\
\hline 1D-6D & 4 & & 3 & 1 & 6 & 2 & & 2 & 1 & 19 \\
\hline $6 \cdot 25 D-12 D$ & 6 & 2 & & 2 & 12 & 5 & 3 & & & 30 \\
\hline $12 \cdot 25 \mathrm{D}+$ & 4 & 5 & & 1 & 11 & 6 & 8 & 4 & & 39 \\
\hline Other & 4 & & & 1 & 3 & 10 & & & & 18 \\
\hline Total & 18 & 7 & 3 & 5 & 32 & 23 & 11 & 6 & 1 & 106 \\
\hline
\end{tabular}

Table 3 Follow-up period after PCC

\begin{tabular}{|c|c|c|c|c|c|c|c|c|c|c|}
\hline \multirow[t]{3}{*}{$\begin{array}{l}\text { Follow-up } \\
\text { (months) }\end{array}$} & \multicolumn{3}{|c|}{$\begin{array}{l}\text { I. Phakic detachment } \\
\text { fellow eye }\end{array}$} & \multicolumn{3}{|c|}{$\begin{array}{l}\text { II. Aphakic detachment } \\
\text { fellow eye }\end{array}$} & \multicolumn{2}{|c|}{ III. High myopia } & \multirow{3}{*}{$\begin{array}{l}\text { Strong } \\
\text { family } \\
\text { history of } \\
\text { retinal } \\
\text { detachment }\end{array}$} & \multirow{3}{*}{ Total } \\
\hline & \multirow{2}{*}{$\begin{array}{l}\text { (a) Giant } \\
\text { tear (FE) }\end{array}$} & \multirow{2}{*}{$\begin{array}{l}\text { (b) High } \\
\text { myopia }\end{array}$} & \multirow{2}{*}{$\begin{array}{l}\text { (c) Extensive } \\
\text { peripheral } \\
\text { retinal } \\
\text { degcneration } \\
\text { (TE) }\end{array}$} & \multirow{2}{*}{$\begin{array}{l}\text { (a) Treated } \\
\text { congenital } \\
\text { cataracts }\end{array}$} & \multicolumn{2}{|c|}{ Senile cataracts } & \multirow{2}{*}{$\begin{array}{l}\text { (a) } P C C \\
\text { prior to } \\
\text { lens ex- } \\
\text { traction }\end{array}$} & \multirow{2}{*}{$\begin{array}{l}\text { (b) Extensive } \\
\text { peripheral } \\
\text { retinal } \\
\text { degeneration }\end{array}$} & & \\
\hline & & & & & $\begin{array}{l}\text { (b) PCC } \\
\text { prior to } \\
\text { lens } \\
\text { extraction }\end{array}$ & $\begin{array}{l}\text { (c) } P C C \\
\text { after lens } \\
\text { extraction }\end{array}$ & & & & \\
\hline $6-12$ & 1 & 1 & & 2 & 6 & 4 & 2 & 2 & & 18 \\
\hline 13-24 & 1 & 3 & 2 & 1 & 7 & 7 & 2 & & & 23 \\
\hline $25-72$ & 14 & 3 & 1 & 2 & 19 & 10 & 7 & 4 & 1 & 61 \\
\hline $73+$ & 2 & & & & & 2 & & & & 4 \\
\hline Total & 18 & 7 & 3 & 5 & 32 & 23 & 11 & 6 & 1 & 106 \\
\hline
\end{tabular}


approximate $270^{\circ}$ stage in the 3 eyes with previous retinal detachment surgery. Seven eyes underwent cryopexy under general anaesthesia at the time of retinal detachment surgery in the other eye, 1 of which was a $360^{\circ}$ stage PCC and 6 were $180^{\circ}$ stage PCC. Local anaesthesia as eye drops was used for 13 of the $156180^{\circ}$ stage PCC applications and for 4 of the 14 eyes which required cryopexy to fill in untreated gaps. The remaining cases were treated under general anaesthesia.

\section{RETINAL DETACHMENTS}

There were 8 retinal detachments which clearly divided into early extensive and late localised retinal detachments.

\section{Early extensive retinal detachment}

Case 1 A 52-year-old emmetropic male with previous ARD in the fellow eye. The treatment eye had been aphakic for 6 years. Preoperatively 3 small round holes were visualised in the upper nasal periphery. Two weeks after upper-half PCC an almost total retinal detachment developed. The retina reattached after an encirclement, and 4 years later the visual acuity was $6 / 5$.

Case 2 A 50-year-old hypermetropic (+4.00 DS) male with a previous ARD in the fellow eye. The visual acuity of the treatment eye was reduced to $6 / 36$ owing to a dense cataract. Four weeks after upper-half PCC he developed an upper-half retinal detachment with a detached macula. No retinal break was visualised. The retina reattached after encirclement and circumferential plombage, and 8 weeks later an uneventful intracapsular cataract extraction was performed. Ten months later the visual acuity was $6 / 18$.

Case 3. A 55-year-old myopic (-11.00 DS) male with a previous ARD in the fellow eye. Two-stage PCC was followed 3 months later by an uneventful intracapsular cataract extraction when the visual acuity improved to 6/9. Seven months later he developed an inferotemporal retinal detachment with the macula attached. There was a round hole at 5 o'clock and a horseshoe tear at 6 o'clock which were both situated equatorially in untreated retina between areas of nonconfluent choroidoretinal cryopexy scarring. After encirclement the retina flattened, and 26 months later the visual acuity was $6 / 5$.

Case 4. A 67-year-old myopic (-14.5 DS) female with a previous ARD in the fellow eye. The treatment eye had chronic simple glaucoma and a drainage operation 9 years previously. Areas of equatorial lattice degeneration were visible at 6 o'clock and 9 o'clock. One-stage $360^{\circ}$ PCC was followed 3 months later by an uneventful intracapsular extraction.
Eleven weeks later an inferior retinal detachment developed. The choroidal retinal cryopexy reaction was not confluent, but no retinal break was visualised. The retina flattened after an encirclement, and 16 months later the visual acuity was $6 / 36$.

\section{Late localised retinal detachment}

Case 5. A 26-year-old highly myopic male with a congenital nystagmus and a previous retinal detachment with a giant tear in the fellow eye. Twentyeight months after 2-stage PCC a localised retinal detachment with a round hole and free operculum was found equatorially in the upper nasal quadrant in normal retina between areas of nonconfluent choroidoretinal cryopexy reaction. After an encirclement and further cryopexy the retina flattened and the visual acuity remained at the preoperative $6 / 24$ 17 months later.

Case 6. A 38-year-old myopic (-8.5 DS) female with a previous retinal detachment and giant tear in the fellow eye. Two-stage PCC was followed 6 months later by further cryopexy to fill in untreated gaps. Three years later a localised retinal detachment with a horseshoe tear was found in the upper temporal periphery anterior to confluent cryopexy reaction. The retina flattened after local plombage, and 2 years later the visual acuity remained at the preoperative 6/18.

Case 7. A 49-year-old emmetropic female with a previous aphakic retinal detachment in the fellow eye. The treatment eye had been aphakic for 2 years prior to 2-stage PCC. Three months later a localised retinal detachment with 2 round holes was found in the lower temporal periphery anterior to confluent cryopexy reaction. The retina flattened after an encirclement and photocoagulation and remained flat 1 year later.

Case 8. A 48-year-old myopic ( $-4.00 \mathrm{DS})$ male with a previous retinal detachment and giant tear in the fellow eye. Four and a half years after 2-stage PCC a localised retinal detachment with a horshoe tear was found at 12 o'clock anterior to confluent cryopexy reaction. The retina flattened after local plombage and cryopexy followed by photocoagulation, and the visual acuity returned to $6 / 6$ postoperatively.

OTHER COMPLICATIONS

Anterior segment. Three cases were noted to have iritis postoperatively, 2 of which were marked. One case had a relapsing course for a year and the second case, aged 13 years, developed iris atrophy, posterior synechiae, and cataract formation and underwent lens aspiration 31 months later. However, this eye had also received intravitreal air and fairly extensive cryopexy amounting to 3 rows. The third 
case suffered a transient iritis which settled on topical steroids. One eye developed early lens opacities 6 months after PCC. Two patients noticed transient loss of accommodation and 1 eye developed a fixed dilated pupil.

Posterior segment. There was one small vitreous haemorrhage, 1 subchoroidal haemorrhage, and 1 small retinal haemorrhage. These all rapidly resolved spontaneously. Three patients developed macular oedema after cataract extraction. The first case had a transient mild macular oedema 6 weeks after cataract extraction which rapidly resolved. The second case had 1-stage PCC 11 weeks prior to an uneventful cataract extraction and had a visual acuity of $6 / 9$ after a year. One year later there was cystoid macular oedema, and when the patient was last seen 3 years after cataract extraction the vision was reduced to counting fingers and there was a lamellar macular hole. The third case had 1-stage PCC 3 months after cataract extraction complicated by vitreous loss. Three weeks later the vision fell from $6 / 6$ to $6 / 18$ and macular oedema was noted. After 21 months the visual acuity was counting fingers and there was macular cystoid oedema.

One eye was noted to have a mild cellophane maculopathy 19 months after 1-stage PCC but retained 6/6 vision. One eye developed a flat horseshoe tear at 12 o'clock behind confluent cryopexy 9 months after 2-stage PCC. This was treated with local plombage and cryopexy without complication.

\section{Discussion}

Two cases of early extensive retinal detachment following PCC have previously been reported. ${ }^{4}$ Both of these were associated with dense cataracts. The evidence of 4 further cases of early generalised retinal detachment suggests that the cause is associated with a nonconfluent circumferential cryopexy reaction. This is technically difficult when opacities of the ocular media are present.

The importance of a confluent cryopexy reaction is further demonstrated by case 5 . Three cases (cases 6,7, and 8) of late localised retinal detachment occurred anterior to confluent cryopexy reaction. Two of these patients had giant tears in the fellow eye. Scott ${ }^{6}$ has stated that between 25 and $75 \%$ of giant tears become bilateral within 5 years. This series had an incidence of $17 \%(3 / 18)$ after an average follow-up of nearly 4 years. It was thought that the 3 retinal tears and detachments were kept localised by the adjacent choroidoretinal reaction and were consequently highly amenable to surgery.

The incidence of aphakic retinal detachment in eyes of which the fellow eye has had an ARD varies between 25 and $43 \% .^{12}$ Of 60 eyes in this category treated with PCC, with an average follow-up period of 29 months, 5 eyes $(8 \%)$ developed retinal detachments.

The marked variation in the incidence of ARD reported by various authors probably reflects the variation in the distribution of myopia within each series. ${ }^{8}$ Hyams et al. ${ }^{9}$ reviewed the literature on the incidence of retinal detachment in myopic aphakia and reported a rate of $7 \%$ in those eyes with 6 or more dioptres of myopia. In this series no detachments occurred in 9 eyes in this category after an average follow-up of 28 months. If the aphakic myopes (>-6D phakic equivalent) with ARDs in the fellow eyes are included, the retinal detachment rate is $4 \cdot 3 \%(2 / 46$, cases 3 and 4$)$.

Delaney and Oates ${ }^{10}$ reported an incidence of $24 \%(23 / 97)$ of retinal detachments in the second phakic eye when the presenting phakic eye was myopic ( $>$ than 3D) with a follow-up period of between 1 and 10 years, compared to a $12 \%(26 / 206)$ incidence when the presenting eye was emmetropic. Törnquist, ${ }^{7}$ with similar numbers, found no difference in the incidence $(13 \%)$ of second eye retinal detachments in the 2 groups.

The literature on the retinal detachment rate in the remaining categories is confused, but only 1 retinal detachment (case 2) occurred in an eye that was not either aphakic or the fellow eye of an eye with a giant tear.

\section{COMPLICATIONS}

In 1978 Kimball et al. ${ }^{11}$ reported a case of cystoid macular oedema occurring 5 weeks after localised choroidoretinal cryopexy. This progressed to a mild cellophane maculopathy 2 months postoperatively. The incidence of macular cystoid oedema was $6 \%$ $(3 / 50)$ in this study after cataract extraction. Prospective studies have shown the incidence of macular oedema after cataract extraction to be $40-47 \% \%^{12} 13$ Gass and Norton ${ }^{14}$ showed that aphakic macular oedema persists for over 3 years in $8 \%$ of cases.

Macular pucker is a reported complication of choroidoretinal cryopexy. ${ }^{45}$ It is of interest that the only case in this series was emmetropic, as the incidence of macular pucker following retinal detachment surgery has been reported to be more common in emmetropes than myopes. ${ }^{16}$ Sourdille and Baikoff ${ }^{17}$ described 2 patients who underwent $180^{\circ}$ prophylactic cryopexy who, 3 months later, were found to have developed vitreous bands with traction macular detachments reducing the visual acuities to 6/60. Robertson and Prilack ${ }^{4}$ reported 2 cases of retinal detachment following PCC which were both followed by extensive vitreous and preretinal membrane formation, and 1 case of preretinal membrane formation involving the inferior macula. 
However, as was stated, considerably greater amounts of cryopexy were used, and all 3 cases were treated in a single-stage procedure. Prospective studies may reveal a higher incidence of mild preretinal fibrosis.

The degree of uveitis from PCC is probably related to the amount of tissue necrosis. ${ }^{18}$ Uveitis may cause cystoid macular oedema. Cryopexyinduced tissue necrosis causes both glial cells ${ }^{19}$ and retinal pigment epithelial cells to proliferate and undergo metaplasia. ${ }^{20}$ These factors have both been clearly implicated in the production of preretinal fibrosis.

The blood supply to the iris and ciliary body is from the long posterior ciliary and anterior ciliary arteries, while the venous return is via the vortex veins apart from the ciliary muscle, which is also drained by anterior ciliary veins. ${ }^{21}$ The selective cauterisation of 3 vortex veins in rhesus monkeys may give rise to a uveal venous stasis ischaemia and eventual anterior segment ischaemia. ${ }^{22}$ Examinations of animal eyes after trans-scleral cryopexy have shown that in the early stages small choroidal vessels show severe stasis while the choriocapillaris becomes obliterated. Larger choroidal vessels remain intact. ${ }^{23}{ }^{24}$ However, a multiple freeze-thaw technique potentiates vascular damage and has been shown to occlude large choroidal arteries and veins. ${ }^{24} \mathrm{~A}$ relative uveal venous stasis is a theoretical risk, though the haemodynamic changes following PCC are not known. Occlusion of the long posterior ciliary arteries has not been demonstrated in either the animal or the human eye. However, endothelial damage must occur, and secondary changes may result in a diminished flow. A quadrant of iris atrophy following $180^{\circ} \mathrm{PCC}$ has previously been described. ${ }^{17}$

There has been 1 previous report in a 36-year-old myopic man who, for over 1 year following $300^{\circ}$ PCC, had a reduction in the amplitude of accommodation and a dilated pupil. ${ }^{25}$ The normal scleral thickness at the equator varies from $0.3 \mathrm{~mm}$ beneath the recti muscles to $0.6 \mathrm{~mm}$. The long posterior and short ciliary nerves lie deep to the equatorial sclera in the suprachoroidal space. ${ }^{21}$ The temperature at this level from a $2 \mathrm{~mm}$ retinal cryoprobe with tip temperature $-60^{\circ} \mathrm{C}$ applied to the external sclera will vary from $-17^{\circ} \mathrm{C}$ to $-32^{\circ} \mathrm{C}$ at 5 seconds. These figures are determined by extrapolation from temperatures determined in $20 \%$ gelatin ${ }^{26}$ and accord with those found experimentally in rabbits. ${ }^{27}$ Lenz et al. ${ }^{28}$ found that a temperature of $-20^{\circ} \mathrm{C}$ for 10 seconds on the sciatic nerve of the rabbit resulted in an absent action potential on rewarming which was still absent when tested 2 days later. However, the rate of rewarming was comparatively slow. Both demyelination of nerve fibres and stasis within blood vessels supplying the nerve are observed after experimental cold injury to peripheral nerves. ${ }^{29}$

The duration of trans-scleral cryopexy application required to produce a visible ice ball at the retina is known to vary widely. Three varying factors are probably responsible, namely, tip temperature, scleral thickness, ${ }^{27}$ and thermal conductivity of adjacent tissues or air. This latter factor makes a comparison between durations of monitored and unmonitored cryopexy applications unreliable. Other authors have suggested scleral applications with durations of between 5 and 10 seconds. ${ }^{26}{ }^{30}$ Most cases in this study underwent monitored cryopexy, and those that were unmonitored had cryopexy applications of between 6 and 10 seconds. In all cases a Keeler-Amoils $2.5 \mathrm{~mm}$ retinal cryoprobe was used with a tip temperature of between $-60^{\circ} \mathrm{C}$ and $-80^{\circ} \mathrm{C}$ and a freezing rate in excess of $50^{\circ} \mathrm{C}$ per second. Clinically it has been found that a 5 -second unmonitored cryopexy application on normal sclera produces a favourable choroidoretinal lesion. Applications on thin equatorial sclera deep to the recti muscles should be of shorter duration, and in very thin pathological sclera where the dark choroid is more easily visible the duration of applications may be as short as 2 seconds.

Monitored cryopexy applications are technically more difficult to apply accurately beneath recti muscles, and it is these zones which are therefore more likely to receive multiple overlapping applications. It would therefore seem prudent to perform cryopexy beneath only 1 horizontal rectus muscle at each stage. In this way the long posterior ciliary nerves and arteries on only 1 side will be at risk, and additionally the anterior ciliary arteries associated with the opposite rectus muscle will not be traumatised.

The technique of PCC application must be aimed, firstly, at utilising efficiently the minimal amount of cryopexy which is efficacious in the prevention of retinal detachment, and, secondly, at minimising the amount of tissue necrosis particularly regarding nerves and blood vessesls. Extending the cryopexy to the ora, as has been suggested by other authors, ${ }^{48}$ is considered to be superfluous and possibly deleterious. Firstly, it will not necessarily decrease the incidence of retinal breaks or localised retinal detachments anterior to the cryopexy reaction. Secondly, no localised retinal detachment anterior to confluent cryopexy has been known to extend posteriorly, and, thirdly, the amount of cryopexy is unnecessarily increased.

In 2 cases, immediately following the second stage inferior PCC and during the same general anaesthetic, an intracapsular cataract extraction with a 
routine superior corneoscleral incision was performed. Although there is no identifiable histological choroidoretinal adhesion up to 8 days following cryopexy, ${ }^{31}$ it probably develops soon after, and an aphakic retinal detachment is unlikely to occur before this. A combined procedure has the advantage of reducing the number of anaesthetics required and, should an early retinal detachment occur, it will be more easily managed with clear ocular media.

The indications for PCC are absolute in fellow eyes of giant tears and in fellow eyes of ARDs when cataract surgery is proposed. The results of further long-term studies, particularly concerning the incidence of preretinal fibrosis, should be awaited before too active a policy is advocated. The indications for PCC must be a balance between the morbidity of the procedure and the risk of leaving the eye untreated. It should be noted that ARDs in patients who have had a previous ARD in the fellow eye have a relatively higher incidence of macular attachment $(57 \%)$ at surgery ${ }^{2}$ and consequently have a more favourable surgical outcome. The morbidity of PCC has been outlined in this paper. However, it must be emphasised that many of these cases were treated when the procedure was first described. It is to be hoped that, by following the guidelines suggested, the morbidity will in the future be even lower.

\section{RECOMMENDED PROCEDURE \\ Cases with clear media}

Cryopexy may be applied across the conjuntiva or direct to the sclera following conjunctival incision. A single continuous row of cryopexy is applied equatorially while monitoring continuously with the binocular indirect ophthalmoscope. It is started above one horizontal rectus muscle and continued superiorly and then below the opposite horizontal rectus muscle. After approximately 1 minute the retina will, except in lightly pigmented fundi, be seen to be oedematous in the treated areas, and then further cryopexy may be applied to untreated gaps. Six weeks later the remaining inferior equatorial hemisphere is similarly treated together with any untreated gaps found superiorly. If, a further 6 weeks later, gaps are found, then further cryopexy may be applied.

\section{Cases with opaque media}

This category includes cases in which the freezing from the cryopexy probe is not easily seen. The conjunctiva is incised, the 3 upper rectus muscles are isolated, and 2 marker sutures are placed equatorially superior to one horizontal rectus muscle and inferior to the opposite horizontal rectus muscle. Cryopexy is then applied to the superior equator in a single straight row for approximately 5 seconds per application (less over thin sclera). Six weeks later the inferior equator is treated similarly to join the marker sutures, which are then removed. Lens extraction may be performed after a further 6 weeks. It is mandatory to dilate the pupil fully 2 weeks later to examine the equatorial cryopexy reaction and to apply further cryopexy to any untreated gaps. In patients having a relatively high anaesthetic risk, it may be possible to perform cataract extraction during the same anaesthetic as the second-stage $180^{\circ}$ cryopexy, though the relative risks of this combined procedure have yet to be assessed.

I thank the members of the consultant staff of Moorfields Eye Hospital, High Holborn, for allowing this study of their patients, the many consultants who replied to my correspondence, Mr J. R. Hudson for reading the manuscript, and Mr J. J. Kanski for helpful discussion.

\section{References}

1 Campbell CJ, Rittler MC. Cataract extraction in the retinal detachment-prone patient. Am $J$ Ophthalmol 1972; 73: 17-24.

2 Benson WE, Grand MG, Okun E. Aphakic retinal detachment: Management of the fellow eye. Arch Ophthalmol 1975; 93: 245-9.

3 Hudson JR, Kanski JJ. Prevention of aphakic retinal detachment by circumferential cryopexy. Mod Probl Ophthalmol 1977; 18: 530-7.

4 Robertson DM, Prilack IA. 360 degree prophylactic cryoretinopexy. A clinical and experimental study. Arch Ophthalmol 1979; 97: 2130-4.

5 Borish IM. Clinical Refraction. 3rd ed. Chicago: Professional Press, 1970; 980.

6 Scott JD. Equatorial giant tears affected by massive vitreous retraction. Trans Ophthalmol Soc UK 1976; 96: 309-12.

7 Törnquist R. Bilateral retinal detachment. Acta Ophthalmol Kbh 1963; 41 : 126-33.

8 Scott JD. Prophylaxis in retinal detachment surgery. Trans Ophthalmol Soc UK 1978; 98: 190-4.

9 Hyams SW, Bialik M, Neumann E. Myopia-aphakia. Prevalence of retinal detachment. Br J Ophthalmol 1975; 59: 480-2.

10 Delaney WV, Oates RP. Retinal detachment in the second eye. Arch Ophthalmol 1978; 96: 629-34.

11 Kimball RE, Morse PH, Benson WE. Cystoid macular edema after cryotherapy. Am J Ophthalmol 1978; 86: 572-3.

12 Irvine AR, Bresky R, Crowder BM, Forster RK, Hunter DM, Kulvin SM. Macular edema after cataract extraction. Ann Ophthalmol 1971; 3: 1234-40.

13 Hitchings RA, Chisholm IH. Incidence of aphakic macular oedema. A prospective study. Br J Ophthalmol $1975 ; 59:$ :44-50.

14 Gass JDM, Norton EWD. Follow-up study of cystoid macular edema following cataract extraction. Trans Am Acad Ophthalmol Otolaryngol 1969; 73: 665-82.

15 Chignell AH, Shilling J. Prophylaxis of retinal detachment. Br J. Ophthalmol 1973; 57: 291-8

16 Lobes LA, Burton TC. The incidence of macular pucker after retinal detachment surgery. Am J Ophthalmol 1978; 85: $72-7$. 
17 Soudille $\mathrm{Ph}$, Baikoff G. Lésions de la macula aprés cryoapplication sclerale. Bull Soc Ophtalmol Fr 1972; 85: 631-8.

18 Lincoff HA, McLean JM. Cryosurgical treatment of retinal detachment. Part II. Am J Ophthalmol 1966; 61 : 1227-34.

19 Bellhorn MB, Friedmann AH, Wise GN, Henkind P. Ultrastructure and clinicopathologic correlation of idiopathic preretinal macular fibrosis. Am J Ophthalmol 1975; 79: 366-73.

20 Robertson DM, Buettner H. Pigmented preretinal membranes. Am J Ophthalmol 1977; 83: 824-9.

21 Warwick R. Wolff's Anatomy of the Eye and Orbit. 7th ed. London: Lewis, 1976.

22 Hayreh SS, Baines JAB. Occlusion of the vortex veins, an experimental study. Br J Ophthalmol 1973; 57: 217-38.

23 Lincoff HA, McLean JM. Cryosurgical treatment of retinal detachment. Part II. Trans Am Acad Ophthalmol Otolaryngol 1966; 70: 202-11.

24 Amoils SP, Honey DP. Early cryosurgical chorioretinal microcirculatory changes. Arch Ophthalmol 1969; 82: 220-8.

25 Pruett RC. Internal ophthalmoplegia after panretinal therapy. Arch Ophthalol 1979; 97: 2212.

26 Amoils SP. Cryosurgery in Ophthalmology. London: Pitman, 1975.

27 Birch PG, Welch RB. Cryosurgery. Int Ophthalmol Clin 1967; 7: 325-34.

28 Lenz H, Goertz W, Pruessler H. The freezing threshold of the peripheral motor nerve: an electrophysiological and light-microscopical study on the sciatic nerve of the rabbit. Cryobiology 1975; 12 : 486-96.

29 Denny-Brown D, Adams RD, Brenner C, Doherty MM. The pathology of injury to nerve induced by cold. $J$ Neuropathol Exp Neurol 1945; 4: 305-23.

30 Kelman CD. Atlas of Cryosurgical Techniques in Opthalmology. St Louis: Mosby, 1966: 98.

31 Feman SS, Smith RS, Ray GS, Long RS. Electron microscopy study of cryogenic choroidoretinal adhesions Am J Ophthalmol 1976; 81 : 823-32. 